\title{
STRANGE ENCOUNTERS IN PLACE STORIES
}

\section{Ingrid Marie Kielland}

Centre for women and gender studies, UIT The Arctic University of Norway, Troms $\phi$, Norway

Corresponding details: Ingrid M Kielland, Finnhvalveien 45, N-9100 Kvaløysletta, NORWAY. ingrid.marie.kielland@uit.no 


\section{STRANGE ENCOUNTERS IN PLACE STORIES}

This paper will explore place stories as a site of encounter between different constructions of place, indigeneity, and strangers. The paper shows how place stories used by local actors debating a would-be Olympic bid from the Northern Norwegian town Troms $\varnothing /$ Romsa were premised on different versions of "us", "they" and "the strangers". While indigenous Sami pasts and presents of the town were drawn upon in the branding of the bid, there is an inherent ambiguity in many actors's stories about Troms $\varnothing /$ Romsa, which contributes to an ambivalent sense as to what it means to be Sami, and to whether Tromsø is a Sami town. The paper examines four different stories about Troms $\varnothing /$ Romsa from which different versions of "strangers" emerge, and discusses the use of place stories and stranger stories as discursive resources for actors arguing both for and against a particular political outcome.

Keywords: strangers; place stories; indigeneity; Olympic place branding

\section{Introduction: Encountering strangeness in place stories}

It is exotic that we have got, that the Sami live here, and it is sort of the wrong way to put it, they have always lived here of course, mostly before we came, but the fact that we, yes, that we have got two cultures that are the same and equal, I think that will be an advantage in the marketing of an Olympics in Troms $\varnothing$. Whether the Sami would feel that an Olympics would be something that they would want to be involved in marketing, I don't know. (local politician discussing the proposed Tromsø Romsa 2018 Olympic bid)

Place stories are established ways of talking and knowing about a place, through which belonging and strangeness, the familiar and the strange(r) are reciprocally produced and negotiated. As exemplified in the interview abstract above, place stories are also sites of strange encounters (Ahmed 2000) between possible versions of "we" and "they". In this case, the "we" being negotiated are the inhabitants of Troms $\varnothing$, a coastal town in Northern Norway, whereas "they" are the indigenous Sami people of the region. The interviewee discusses a proposed Olympic bid from Troms $\varnothing$, and the marketing of the 
bid as co-hosted by Norwegians and Sami. The account can be read as an encounter between place stories that take the Norwegian status of Troms $\varnothing$ for granted, and stories in which the Sami past and present of the town is acknowledged in some form. The particularities of the encounter are of course premised on the discursive context in which the stories were used, and on the possible subject positions available to the narrator. While stating that Troms $\emptyset$ is both Norwegian and Sami, the account draws on ambiguous stories about the Sami as "familiar strangers", being referred to as both exotic, indigenous, the same and equal, yet inherently Other (Said 1978) than the Norwegian subject position of the narrator.

This article aims at exploring the potential of approaching strange encounters through place stories and stranger stories. Through a case-study of the use of place stories in relation to the would-be Troms $\varnothing$ Romsa 2018 Olympic bid, I will examine different kinds of strange encounters and negotiations of strangeness in relation to place. Place stories are flexible narrative resources (Potter and Wetherell 1987, Wetherell and Potter 1992, Taylor 2010) that can be used in different ways in different discursive contexts. They can be mobilized both to include and exclude, and can discursively produce both objects of strangeness and subjects of belonging. As such, place stories are also stranger stories, in which "locals" and "strangers" are reciprocally produced. Indigeneity offers a fruitful vantage point from which to explore the relational and flexible nature of stranger stories. As an indigenous population with no foreign homeland to return to, the Sami are not "conditional strangers", nor are they "outsiders" in Rundell's (2004) use of these concepts. Rather the Sami are conditionally produced as strangers through place stories in which the "we" of the nation state either excludes them or renders their distinctive history and culture invisible. Their position as "native yet strangers" is ambivalent, as it entails the possibility of being assigned to more than 
one category (Baumann, 1991). Place stories provide a site for negotiating these assignations in relation to other possible place-based identities. As underlined by Koefoed and Simonsen (2011) and Jackson, Harris and Valentine (this issue), the stranger is best thought of as a relational figure, and stranger stories provide different ways of approaching relationships of insider/outsider in place.

I begin by setting out the conceptual framework for an exploration of how rights of belonging, non-belonging and strange encounters can be understood and negotiated through place stories. I will also comment on methods, including a note on my own positionality as a Norwegian scholar in this context. Following this I will introduce Troms $\varnothing$ Romsa and the Olympic bid, and explore four different stories about Sami belonging or non-belonging in Troms $\varnothing$. In conclusion I will return to the question of how different strangers emerge in place stories, and argue that strange encounters in place stories may reproduce but also provide opportunities for renegotiating strangeness.

\section{Approaching strange encounters through place stories}

Place stories are recognized articulations or ways of understanding and talking about particular places. Together with other established narratives they constitute an interpretative repertoire that actors may draw upon in their discursive practices (Taylor 2010). Place stories link together descriptions, "facts" and taken for granted knowledges in order to make sense of the social and physical amalgamations that make up a place. Because places can be understood both as locations and locales, and as symbolic and emotional entities, place stories often tend to combine interpretative repertoires of identities, interests and materialities. Place is always in the making, being constituted through trajectories and relations that may be both proximate and farreaching (Massey 1994, 2005). Place stories are attempts towards making sense of 
multiple and changing borders and affinities, and may draw on different repertoires of propinquities and (dis)connectivities (Amin 2004). Place stories can be understood as both means for and products of negotiations between different actors over place, through which strange encounters may occur. Consider for example the encounter in the introduction between a story about place which is based on the majority-population of a nation state, in which an indigenous past and/or present has no natural expression, and a story in which the indigenous is explicitly included, although perhaps in terms and forms that may be further contested. One product of such negotiations and contestations is strangeness. Who is the stranger, and what is the meaning of her strangeness in a given circumstance? Place stories are moral geographies (Lee and Smith 2004) that work to establish what activities are possible and desirable in a given place, who can belong and what rights they have. Through place stories some actors are recognized as legitimate participants in place politics, whereas other actors by the same token are excluded or made invisible (Lister 2003, Mouffe 1992). As argued by Ahmed (2000), stories about belonging depend on the figure of the stranger as "a means by which the 'we' of the community is established, enforced and legitimated" (Ahmed 2000: 37). But the content given to the stranger-figure may change depending on the stories used, the context in which they are told and the discursive work they do. Postcolonial research and politics have often aimed at reinstating or retelling place stories that had been previously silenced. However Nash (1999) warns that neither anti-colonial revival or an outright dismissal of any authentic truth about place are adequate in dealing with the cultural complexities of locations that have been marked by colonial relationships. Ahmed's (2000) personal story about passing as white through denying to be Aboriginal, which subsequently classified her "as somebody who has a legitimate right to walk in these leafy suburbs" (Ahmed 2000: 129) is a good example of how identity- 
stories are also statements about interests, while stories about interests can be used to discuss and negotiate understandings of identities. While place stories and stranger stories produce identities, they are also means for producing and defending interests. The production of identities and the production of economic divisions should be understood as relational and reciprocal (McDowell 2004). Staeheli (2008) argues that political claims for the recognition of identity and difference are also reflections of political and economic differences in society, and that "expressions of identity and difference in public realm have implications for the quality of democracy and citizenship" (Staeheli 2008: 562-563). Place stories are discursive resources that may be used by actors to claim recognition not only of their identity and belonging but also of their interests in place. Likewise, place stories may be used to construct particular actors or groups as strangers in a way that will delimit their chances of making claims, both about identity and about interests. While stories are flexible resources that can be used in many different contexts to do different things, their acceptance by other actors are not given. Place stories about identity may be disputed or challenged by stranger stories. Diken (1998) has described how the construction of an area as poor or ghetto may pose a potential problem for residents of that area in their identity stories about themselves and their sense of belonging. As noted by Jenkins (2000) group identities are shaped through an internal-external dialectic between self-image or personal identity stories and public-image through the construction of their identities in collective place stories. Kofoed and Simonsen (2011) in their study of Copenhagen residents of Pakistani origin have described how "a range of spatialities (...) are involved in the constitution of the stranger, and the figure can take different shapes and different roles depending on the context in which it is performed" (Koefoed and Simonsen 2011: 355). Actors may use 
different place stories about belonging at different geographical scales, so that the stranger vis-à-vis the nation may still be at home in the capital city.

The place stories discussed in this paper are drawn from semi-structured qualitative research interviews conducted from November 2008 until July 2009, as part of a larger research project about place politics and place stories in relation to the would-be Olympic bid from Tromsø/Romsa (Kielland 2012). The interviewees were local inhabitants who had involved themselves in the Olympic debate in Troms $\varnothing$, either as organized opponents or proponents, or as participants in a public meeting arranged by the municipality. Interviewees were not selected on the basis of ethnicity but on the basis of their participation in the local debate. Three out of 24 interviewees identified themselves as Sami, whereas one described himself as Kven (regional minority group of Finnish origin). The other 20 did not describe themselves in ethnic terms, and their status as Norwegian was thereby tacitly taken for granted in the discursive context of the interview. Actors quoted are not identified by name or pseudonym, in order to avoid the many discursive presumptions that a name or pseudonym may carry (Taylor 2010). Local belonging and the Sami branding of the bid were issues that were discussed in all the interviews. The aim was to produce empirical data on how actors used different stories about identity and belonging in spoken discursive practices. It is important to recognize that research interviews are a particular type of discursive setting and that the interviewers line of questioning inevitably invites interviewees to speak within certain discursive frames. On the other hand, the interview will relate to other discursive settings that actors participate in, as both interviewer and interviewee are dependent on a shared interpretative repertoire in order to "make sense" to each other. As argued by Mik-Meyer and Järvinen (2005), meaning is created interactionally and in relation to various other contexts. In analysing the place stories discussed in this paper, the 
analytical focus has been on how stories about Troms $\varnothing /$ Romsa and the Sami were used as discursive resources by the interviewees and what kind of discursive work they do. Stories were drawn upon not only as arguments for or against the Olympic bid, but also in order to produce plausible reasons and perceived legitimate subject positions from which to make these arguments. In particular the analysis aims at showing how the place stories work to produce different versions of a majority "we" and a minority "they, the strangers".

As a Tromsø-inhabitant myself, and a member of the Norwegian majority population, the stories and negotiations that are discussed in this article are to some extent also stories that affect my own subject positions. I find it poignant to acknowledge that there are certain dilemmas related to writing about the positioning of the indigenous from a majority position. Ahmed (2010) has noted the problematic use of academic knowledge by members of the majority population in producing and defining Australia's aboriginal population as strangers, arguing that "knowledge allows the stranger to enter the community as a figure" (Ahmed 2010: 54). The right to and the capacity for producing scholarly knowledge about indigenous topics is a contested issue in the Nordic context as well (Keskitala 1997). Stordahl (2008) recommends that "researchers, regardless of their ethnicity, analyse their own as well as their colleague's research in order to discover what perspectives and interests they represent" (Stordahl 2008: 262). My aim in discussing the stories about Troms $\emptyset$ Romsa is to examine how different positions are produced as strange through stories about place. In doing this, I have tried to reflect on the tacit assumptions that my own majority subject position may entail, while also accepting that there are no authentic or innocent positions on place and belonging. As noted by Valentine (2002) sameness and difference will always have to be negotiated as part of a research project. 


\section{Tromsø Romsa - A contested place story}

Troms $\emptyset$ is the largest town and regional centre of Northern Norway. It is also one of the largest towns in Sapmi, the area traditionally inhabited by the indigenous Sami population of Norway, Sweden, Finland and Northwest Russia (see figure 1). The Sami name for Troms $\varnothing$ is Romsa. Troms $\varnothing$ has got 70358 inhabitants ${ }^{1}, 1161^{2}$ of who have identified as Sami in the Sami voting register.

Note: Insert figure 1, map Tromsф and Sapmi.

Figure 1: Map depicting Norway, Sapmi and Tromsø (C) Tove Midthun

Northern Norway has a long history of co-inhabitance by people of what today is called Norwegian and Sami heritage (Munch 2013). Troms $\varnothing$ was established as a trading town within the Danish-Norwegian state by royal decree in 1794. Despite archeological and historical evidence of Sami inhabitance and usage of the area which today comprises the municipality of Troms $\varnothing$, the Sami past and present identity of Troms $\varnothing$ continue to be contested (Brantenberg \& Storm 2013). The use of Sami place names and language is controversial, dating back to the rigid Norwegianisation policies that were effectuated by the state from the late $19^{\text {th }}$ century and into the first postwar decades (Niemi 1997, Minde 2005). Norwegianisation policies aimed at assimilation through state institutions such as compulsory boarding schools and the church. Because of Norwegianisation, knowledge of Sami language deteriorated and became more or less extinct in many coastal areas (Magga, 2004). Census data from this period also shows that the number

\footnotetext{
${ }^{1} 1.1 .2013$, SSB (Norwegian state statistical bureau).

2 7.8.2013, Sametinget (Sami parliament of Norway).
} 
of residents identifying themselves as Sami dropped in many municipalities, and that residents changed their ethnic identification from Sami to Norwegian when they moved to urban municipalities such as Tromsø (Hansen 2013). As a result, Sami became "invisible strangers" in large parts of Northern Norway. State policies towards the Sami have gradually changed, with the conflict over the damming of the Alta river in the early 1980s an important historical turning point (Eidheim 1997). In 1989 the Sami Parliament of Norway was opened and the Norwegian constitution was amended to include a passage about the responsibility of the State for enabling the Sami to preserve and develop their language, culture and way of life (Minde 2003). In the decades that have followed, Sami language and culture have been revitalised, but there have also been internal and external disagreements and contestations over Sami identities and rights (Thuen 2003, Andersen 2003). The use of an indigenous past and present to promote the Olympic proposal from Troms $\emptyset$ should also be understood in the context of wider Sami revitalisation processes and contestations in the region.

The proposal that Troms $\varnothing$ should make a bid to host the Winter Olympic Games was first announced in 2003. After 5 years of preparing a bid for 2014 and later 2018, the project was finally abandoned by the Norwegian Olympic committee in 2008. While the bid was supported by many local and regional actors (politicians, businesses, sports enthusiasts and activists), it was also disputed by local politicians and activists. Popular support varied throughout the project period, ranging from $40-70 \%$ of Troms $\emptyset$ inhabitants in favour. The final scrapping of the bid by the national decision-making level was premised on a negative external report on the costs involved. Although the bid was never realized, the debate about it contributed to highlighting different stories about Troms $\varnothing^{\prime}$ s past and possible future trajectories. Among these were the different stories about the role of the Sami in Troms $\varnothing$. When the proposal was first announced in 2003, a 
Sami-Norwegian co-hosting was described as one of the five pillars of the bid. A story about Troms $\emptyset$ as an indigenous town was drawn upon as a positive attribute. Tromsø's past and present Sami identity was stated as a matter of fact, and used to promote the bid through naming the proposal Troms $\varnothing$ Romsa 2014 (2018). Sami symbolism was widely used in the production of documents and promotional material for the would-be bid. The claim that Troms $\varnothing$ Romsa was to include "a participatory indigenous dimension"” was also backed up by official endorsement from the Sami Parliament.

Among the interviewed opponents and proponents of the Olympic bid, attitudes towards the Sami in general and the Troms $\varnothing$ Romsa branding in particular varied from positive endorsement to outright rejection. Individual actors would draw on several different and sometimes conflicting stories about the town and the Sami in their discursive practices. Four different stranger stories emerge from the interviews. These can be epitomized as "The Sami are strangers", "The Sami are aesthetic strangers", "The Sami are not strangers" and "We are all strangers".

\section{The Sami are strangers}

Some actors rejected the notion of Troms $\varnothing$ Romsa and a Sami place identity altogether. One interviewee, associated with a populist right-party whose representatives had voted against the Olympic bid in the municipal council, described the Sami profiling of Tromsø through the Olympic project as a provocation.

\footnotetext{
${ }^{3}$ Troms $\emptyset 2018$ AS.2007. Lenger nord enn noen gang. Troms $\phi$ 2018. S $\phi$ kerby for de XXIII Olympiske Vinterleker og de XII Paralympiske Vinterleker i 2018. (Further North than Ever. Troms $\emptyset$ 2018. Bidder for the XXIII Olympic Winter Games and the XII Paralympic Winter Games of 2018). Proposal document presented to the Norwegian Confederation of Sports February 2007.
} 
Yes, that was actually something which made me very annoyed every time I saw it, that Troms $\varnothing$ Romsa 2018, trying to portray Troms $\varnothing$ as a Sami town, and there are more Sami living in Oslo than in Troms $\varnothing$, so that was something I reacted very strongly against and thought it was just stupid. (...)[They are] trying to create connotations to the Sami on the mountain plateaus with a tent and a reindeer, that's not what it's like in Tromsø.

The story drawn upon in this interview extract positions Troms $\emptyset$ as a Norwegian town in which Sami symbolism has no place. By referring to the Norwegian capital Oslo as having more Sami inhabitants than Troms $\varnothing$ (based on the Sami electoral register), the presence of Sami in Troms $\emptyset$ is removed from a historical context and linked to a contemporary situation of indigenous rural-to-urban migration. As noted by Cardinal (2006) the discursive linking of indigenous people with rural areas have tended to marginalize urban indigenous dwellers, and in this case it was used to distanciate the urban location from its indigenous population. In the extract, Sami are described as strangers whose traditional livelihood and way of life is out of time as well as out of place in Tromsø. They are relegated to "the mountain plateaus", and deemed as irrelevant in the town.

While the former interviewee's rejection of Troms $\emptyset$ as a Sami town was used as argument against the Olympic bid, not all interviewees who described the Sami as strangers were opposed to the project. One Olympic proponent who had himself moved to Troms $\varnothing$ as an adult drew upon a story about the Sami as strangers in the town to explain his own sense of partial belonging in the town. When asked if he felt like a true Troms $\varnothing$-inhabitant, he replied that to a certain extent he did.

Yet, as long as you speak a different dialect and have a family with high cheekbones, you always feel like some of your roots remain outside the town..

Having high cheekbones is a physical feature that in this story about place and 
belonging was explained by the narrator as indicative of his indigenous Sami heritage. He argued that his Sami background together with his dialect from a neighboring county was something that was not "typical" and set him apart as a stranger in Tromsø. The high cheekbones worked as a symbolic mark of difference, which to this narrator made him recognizable as "the body out of place" (Ahmed 2000: 39). However, when queried if this sense of not belonging because of a Sami heritage meant that he thought Troms $\varnothing$ was not a Sami town, the man protested that he certainly thought of Troms $\varnothing$ as having a Sami identity. He argued that there was historical evidence of a long-lasting Sami inhabitance in Troms $\varnothing$, and that the Norwegian name of the town had in fact been derived from the Sami name Romsa. He also referred to a vibrant Sami milieu in present-day Troms $\emptyset$, and even returned to the story about high cheekbones as a Sami feature in arguing that people on Tromsø's Main Street had "somewhat higher cheekbones" than they did in Oslo or other places in Southern Norway. The bodily feature related to being out of place in the story he told about his own sense of Sami non-belonging in the town was thus reworked as a sign of Sami identity and belonging in an Olympic story about Troms $\varnothing$ as Romsa. This shows that stories about place and indigenous belonging are often ambivalent and flexible and can do different discursive work in different contexts.

Another interviewee, who also supported the bid, argued that Troms $\varnothing$ was not a Sami town because the Sami were only a marginal proportion of the population. She described Troms $\varnothing$ as a Norwegian town with an international outlook, and argued that the Sami presence should be understood in relation to tolerance of difference.

It's okay that Troms $\varnothing$ has a Sami school such as Prestvannet where the kids can be in a Sami class if the parents want that, and the school observes the Sami National Day. That's open and inclusive. 
By describing Sami cultural practices as acceptable or okay, the narrator draws upon a story of the majority population as generous hosts who may offer hospitality (Bell 2010). This story at the same time positions the Sami as strangers, whose access to schooling in their own language or ability to uphold their cultural practices are seen as a privilege granted by the majority, not a right. This story about the majority population as hosts is premised on forgetting or silencing the status of the Sami as an indigenous people. As noted by Bell (2010), the position of the majority-population as the sovereign people of the nation may be put into question by the tacit or explicit recognition of a colonial past.

\section{The Sami are aesthetic strangers}

Among actors who supported the Olympic bid, there was a general acknowledgement that the Tromsø Romsa name was part of the Olympic "package". The use of Sami culture and inclusion of Sami representatives in the Olympic bidding committee was described as a tactical choice. One actor noted that indigenous representation was an important part of what could be called the established Olympic story.

And I do think it was important to have a Sami representative included when they were going abroad to talk to the world. Because all the other Olympics, or many other Olympics, especially in the opening ceremony have had a link to the genuine and authentic in the different regions.

The use of indigenous cultures and histories is of course an established element of Olympic discourses, seen for example in Sydney 2000 and Vancouver 2010, although criticism has been raised that this indigenous symbolism is tokenistic and superficial (Garcia 2007).The story about the Romsa-branding as part of the Olympic package seems to support this criticism. Another proponent described the Sami profiling and focusing on indigeneity as a little kitsch. 
It's a tourist event in many ways this thing, and you should perhaps fudge it a bit (...)it's a necessity and one has to dare to do that, the Olympic Games are a bit of a cliché, and that's allowed, it's supposed to sell on American television...

These proponents seem to draw on a story about Sami culture as something exotic that can be used to attract tourism and to provide added value to an Olympic hosting as an aesthetic dimension. Siv Ellen Kraft (2004) explicates that Sami culture and heritage was an important part of the "arctic magic" which the Troms $\emptyset$ Romsa bid promised to deliver. Again the Sami are positioned as strangers, whom it is considered profitable to make available for aesthetic consumption by an international television audience. As Ahmed (2000) would put it, they would "eat the stranger".

The story about the Sami as aesthetic consumption of the Sami was used as an argument against the Olympic bid by actors who were critical of the project. In the words of one interviewee:

I think that the Sami, as seen so many times before, were used (...) They just glued the Sami on to [the bid] like a kind of colonial, sort of "hey, here we have some funny pygmies next to our new barrel factory in the Amazonas. Here they are with their spears, oh dear how exotic it is." Pure humbug.

The quote has similarities with postcolonial critiques (Loomba 1998/2005) of the exotification of indigenous people for entertainment purposes by business interests in other parts of the world. The interviewee classified this exotification as a scam, and accused the Olympic bidding committee of using a story about the Sami as exotic strangers in order to promote other interests. Interestingly, as a majority Norwegian the actor also ends up reiterating the classic dilemma in postcolonial theory of the majority speaking of/for the subaltern (Spivak 1988). 


\section{The Sami are not strangers}

Among the centrally involved Olympic proponents, those who had been working for or in connection with the bidding committee, most were committed to the story of Troms $\varnothing$ Romsa and used this as an argument for the bid. These actors tended to state unequivocally that Troms $\emptyset$ was both a Sami and a Norwegian town. One interviewee drew on both the present and historical presence of Sami people in Troms $\varnothing$ as well as in the Northern Norwegian region to support this view:

There are many Sami living in Troms $\emptyset$, we have a Sami history and we are sort of a central meeting place for the entire Northern Norwegian, and to an extent the Norwegian, Sami culture.

Several interviewees referred to the Sami kindergarten in Troms $\varnothing$, as well as Sami classes in school as an example of Troms $\emptyset$ being a Sami town, and one argued that Troms $\varnothing$ 's Sami profiling was based on having a a special position in the region.

I think it's a natural thing, given that Tromsø is the largest town in Northern Norway.

In these accounts, Troms $\varnothing$ 's Sami identity was premised not only on local aspects such as number of Sami inhabitants of Sami public services, but also on Troms $\varnothing^{\prime} s$ relationship to the wider Northern Norwegian region. The stress on the region also works as an implicit recognition of Northern Norway as a part of Sapmi, although this was not spoken. The Sami are thus recognised as different, but not really strangers. They are described as a distinct people with a distinct culture, yet seen an integrated part of the town and the region. This description of the Sami as an integrated part of the town corresponds with findings by Nyseth and Pedersen (2014) who argue that a growth in the number of Sami living in urban areas, particularly Troms $\varnothing$, has created more opportunities for Sami revitalisation and given new generations of Sami new ways of 
being "City-Sami".

Actors associated with the activist network No to the Olympics generally tended to endorse the Olympic committees' description of Troms $\emptyset$ as Sami, although they criticized the Romsa branding on account of the Olympics being seen as detrimental to Sami interests. Several interviewees used the expression "cake decorations" in response to my question about the bid's Sami profile. One actor put it this way:

I think that it was just icing on the cake to them. But yes, the Sami aspects are a part of the culture here, yes, I think that is absolutely obvious. (...) For me who belongs in Troms $\varnothing$, who is born and raised here (...), the Sami aspects are a completely natural part of us and the things that are here, so I think it is kind of artificial to highlight it so much.

Note the way the actor uses a story about being "born-and-bred" (Taylor 2010) in Troms $\varnothing$ as a way to reinforce her argument that Sami aspects are an inhererent part of the local culture. The account draws on a story about Sami culture as something that is ordinary, part of everyday life, and again works to position the Sami as "not strangers". The use of Sami symbolism to promote an Olympic bid is categorized as artificial, and the actor uses the term "us" in describing Sami aspects as a natural and inherent part of the town's shared culture. Unlike the aestethic positioning of the Sami seen in the former section, this is a positioning of the Sami as a part of everyday life.

\section{We are all strangers}

The colonial history of Norwegianisation was hinted at by some proponents, who argued that the important thing about the proposed Olympics in relation to Sami aspects was the opportunity to showcase and highlight the Sami presence in Troms $\varnothing$; before, during and after the Games. One actor emphasized that even though the bid had been cancelled, the use of the name Troms $\varnothing$ Romsa during the five years in which the project 
had been promoted was a victory in itself for Sami identity politics. Another discussed the gains that he would have expected had the bid actually been successful. He talked about how the material Olympic heritage of Troms $\emptyset$ Romsa 2018 would include what he called a "symbolic building [...] a very noticeable building which in terms of architecture and design would reflect Sami history and identity." But more important still in his narrative was the immaterial heritage of the Games.

I think that for the people, for the Sami, it would have been a project of pride, where they had been 100 percent represented as hosts, had contributed to creating a success, this would have meant a lot to the individual. It would have created more pride, more, even more people would have dared to be what many of us in Northern Norway are, which is [people with] Sami ancestors and roots.

Actors who argued that increased visibility would be a positive outcome of an Olympic hosting seem to do so on the basis of an established understanding that Sami culture was hidden and under-communicated. The latter quote implies that Sami people were ashamed of their heritage, and that it was therefore important to render their culture visible and create pride through representation. Note however that although the actor did not identify as Sami himself, he talked about a Northern Norwegian collective identity where many of "us" have Sami ancestors, thus constructing a common regional interest in the increased Sami pride that the Olympic hosting was supposed to create. To some extent this assumed commonality enables the narrator to represent himself as part of a "we" who are all in some way strangers, and to argue that "our" shared identity and shared interests would be promoted through a Sami Olympic branding.

\section{Concluding remarks}

To what extent do place stories enable strange encounters and negotiations of strangerness? The different stories about Troms $\varnothing$, Romsa and the would-be 2018 
Olympic bid indicate that place stories and stranger stories may be mobilized in various ways in place politics. While some proponents of the Olympic bid used a story about Troms $\emptyset$ as Romsa to argue that the Sami people and heritage was part of a regional "we", other proponents challenged the story by underlining that the Sami were strangers to be accepted but not included in the "we" of the majority-population. The desire to draw on the Romsa-story in order to promote the Olympics did nevertheless produce an arena for encounter in which the majority-population story was made visible together with the one that included the Sami heritage. Among the opponents of the bid, some used the Troms $\varnothing$ Romsa-story as a resource for rejecting the bid as well as the Sami branding of the town, whereas others rejected the bid by using the story as a resource for arguing that the Sami were not strangers and the bid was disreputable because of the exotic place branding which represented them as such. Their critique thus worked as a challenge of the bid while at the same time reinforcing the story about Troms $\emptyset$ as Romsa. Place stories contribute to setting the premises for political debate through establishing ways of understanding both the past and the future. Different stories or understandings of the situation at hand make different political projects possible to imagine and promote, and different stories about identity, belonging and strangerness provide different possible political subject positions. Through the stories about Troms $\varnothing$ Romsa 2018, diverse understandings of the town's indigenous history and possible future identity was articulated and thereby made available for encounter, contestations and negotiations. In the years that have passed since the Olympic bid was cancelled, the articulation of Troms $\varnothing$ as Romsa has been further contested, renegotiated and reinforced in local politics. One example of this was a heated controversy in 2011 about Troms $\emptyset$ joining the Sami language administration area, which is managed by the Sami parliament. The stranger stories discussed in this paper were reactivated in this context 
and used to argue for and against a Sami language bill. A compromise was found in 2012, when the mayor of Troms $\emptyset$ signed a less binding agreement with the Sami parliament, pledging to protect Sami language and traditions.

Place stories are cognitive maps through which political actors can imagine future courses of action, but the outcome of political action is not given. In her discussion of social conflicts and processes of transformation in the London Dockland's, Massey states “there are no rules of space and place” (Massey 2005: 163). To paraphrase Massey, I would argue that there are no rules of place stories. Stories about local belonging, rights and traditions can be used to reject the exotification of an indigenous culture or to protest against the remnants of Norwegianisation policies, but the same kind of stories can also be used in rejecting Sami revitalization policies. Stories are discursive resources used, produced and reproduced by actors in order to understand, relate to and act upon a socially constituted social and material world. As such, place stories and stranger stories are also discursive resources for political action. The political potential of stories should however be understood as a relational effect (Allen 2003), and not as an inherent quality of the stories themselves. While discursive practices can be seen as transient, often ambivalent and always contextual, these practices draw on and work through established discursive structures, and in their flexible production of meaning in the moment they also contribute to reproducing and creating new structures of meaning for the future. As argued by Bakhtin (1981), the meaning of a word or of a story "is always half someone else's. (...) It exists in other people's mouths, in other people's concrete contexts, serving other people's intentions" (Bakhtin 1981: 293-294). The structural effects of discursive practices are not always knowable or easy to predict. Therefore it is not always given what is encountered through place stories, or who may emerge as a stranger. 


\section{Acknowledgements}

I would like to thank the special issue editors and two anonymous reviewers for the insightful comments and suggestions that I have received in the process of writing this paper.

\section{References}

Ahmed, S. (2000) Strange Encounters. Embodied Others in Post-Coloniality. London: Routledge

Ahmed, S. (2010) Who Knows? Knowing Strangers and Strangerness. Australian Feminist Studies, 15:31, 49-68

Allen, J. (2003) Lost Geographies of Power. Oxford: Blackwell Publishing Amin, A. (2004) Regions unbound: Towards a new politics of place. Geografiska Annaler. Series B, Human Geography, Vol. 86, No. 1 (2004): 33-44.

Andersen, S. (2003) Samisk tilhørighet i kyst- og fjordområder. In Bjerkli, B. \& P. Selle (eds) Samer, makt og demokrati. Samtinget og den nye samiske offentligheten. Oslo: Gyldendal akademisk.

Bakhtin, M.M. (1989) The Dialogic Imagination. Four Essays. Edited by Michael Holquist. Austin: University of Texas Press

Bell, A. (2010) Being 'at home' in the nation: Hospitality and sovereignty in talk about immigration. Ethnicities Vol 10(2): 236-256

Brantenberg, T. \& D. Storm (2013) Innledning. Ottar nr 295: 2. Tromsø Museum, Universitetet i Troms $\varnothing$

Cameron, E. (2012) New geographies of story and storytelling. Progress in Human Geography October 2012 36: 573-592

Cardinal, N. (2006) The exclusive city: Identifying, measuring, and drawing attention to Aboriginal and Indigenous experiences in an urban context. Cities, Vol 23(3): 217-228

Diken, B. (1998) Strangers, Ambivalence and Social Theory. Aldershot: Ashgate 
Eidheim, H. (1997) Ethno-Political Development among the Sami after World War II: The Invention of Selfhood. In Gaski, H. (ed.) Sami Culture in a New Era. The Norwegian Sami Experience. Karasjok: Davvi Girji

Garcia, B. (2007) Sydney 2000. In Gold, J.R. \& M. M. Gold (eds) Olympic Cities. City Agendas, Planning, and the World's Games, 1896 - 2012. London/New York: Routledge

Hansen, L.I. (2013) Bodde det samer i Troms $\emptyset$ ? Hva folketellingene forteller - og ikke forteller. Ottar $n r$ 295: 25-33. Troms $\varnothing$ Museum, Universitetet i Troms $\varnothing$

Jackson, L., C. Harris \& G. Valentine (2016) Negotiating Strange Encounters: Conceptualising conversations across difference. Social and Cultural Geography, this issue.

Jenkins, R. (2000) Categorization: Identity, Social Process and Epistemology. Current Sociology. Vol 48 No 3: 7-25.

Keskitalo, J.H. (1997) Sami Post-Secondary Education - Ideals and Realities. In Gaski, H. (ed.) Sami Culture in a New Era. The Norwegian Sami Experience. Karasjok: Davvi Girji

Kielland, I.M. (2012) Whose stories, whose place? Place politics and the politics of place stories in Tromsø's Olympic Debate. Dissertation for the degree of $\mathrm{PhD}$, University of Troms $\varnothing$.

Koefoed, L. \& K. Simonsen (2011) 'The stranger', the city and the nation: on the possibilities of identification and belonging. European Urban and Regional Studies 18 (4): 343 - 357

Kraft, S.E. (2004) Et hellig fjell blir til: om samer, OL og arktisk magi. Nytt norsk tidsskrift, Årgang 21, nummer 3/4: 237-249. 
Lee, R. \& D. Smith (eds.) (2004) Geographies and Moralities. International Perspectives on Development, Justice and Place. Oxford: Blackwell

Lister, R. (2003) Citizenship. Feminist Perspectives. Second Edition. Hampshire: Palgrave Macmillan

Loomba, A. (1998/2005) Colonialism/Postcolonialism. Second edition. London: Routledge

Magga, O.H. (2004) Cultural Rights of the Sami People in Norway: Past and Present. In Irimoto, T. \& T. Yamada (eds.) Circumpolar Ethnicity and Identity. Osaka: National Museum of Ethnology.

Massey, D. (1994) Space, Place and Gender. Cambridge: Polity Press

Massey, D. (2005) For Space. London: Sage

McDowell, L. (2004) Masculinity, identity and labour market change: Some reflections on the implications of thinking relationally about difference and the politics of inclusion. Geografiska Annaler. Series B, Human Geography, Vol. 86, No. 1 (2004): 45-56.

Mik-Meyer, N. \& M. Järvinen (2005) Indledning: Kvalitative metoder i et interaktionistisk perspektiv. In Järvinen, M. \& N. Mik-Meyer (eds) Kvalitative metoder $i$ et interaktionistisk perpektiv. Interview, observationer og dokumenter. Copenhagen: Hens Reitzels Forlag

Minde, H. (2003) The Challenge of Indigenism: The Struggle for Sami Land Rights and Self-Government in Norway 1960-1990. In Jentoft, S., H. Minde \& R. Nilsen (eds.) Indigenous Peoples. Resource Management and Global Rights. Delft: Eburon Academic Publishers

Minde, H. (2005) The Alta case from the local to the global and back again. In Cant, G., A. Goodall \& J. Inns (eds.) Discourses and Silences. Indigenous Peoples, Risk 
$s$ and Resistance. Christchurch: Department of Geography, University of Canterbury

Mouffe, C. (ed.) 1992. Dimensions of Radical Democracy. Verso, London.

Munch, G.S. (2013) Tre kvinner fra vikingtidens stor-Troms $\emptyset$. Ottar nr 295: 19-24. Tromsø Museum, Universitetet i Troms $\varnothing$

Nash, C. (1999) Irish placenames: post-colonial locations. Transactions of the Institute of British Geographers, NS 24: 457-480

Nyseth, T. \& P. Pedersen (2014) Urban Sámi Identities in Scandinavia: Hybridities, Ambivalences and Cultural Innovation. Acta Borealia: A Nordic Journal of Circumpolar Societies, 31:2, 131.151

Niemi, E. (1997) Sami History and the Frontier Myth: A Perspective on the Northern Sami Spatial and Rights History. In Gaski, H. (ed.) Sami Culture in a New Era. The Norwegian Sami Experience. Karasjok: Davvi Girji

Potter, J. \& M. Wetherell (1987) Discourse and Social Psychology. Beyond Attitudes and Behaviour. Sage, Los Angeles.

Rundell, J. (2004) Strangers, Citizens and Outsiders: Otherness, Multiculturalism and the Cosmopolitan Imaginary in Mobile Societies. Thesis Eleven, Number 78: 85101

Said, E.W. (1978) Orientalism. London: Penguin Books

Staeheli, L.A. (2008) Political geography: difference, recognition, and the contested terrains of political claims-making. Progress in Human Geography 32(4): 561570.

Stordahl, V. (2008) Nation Building Through Knowledge Building: the Discourse of Sami Higher Education and Research in Norway. In Minde, H. (ed) 
Indigenous Peoples: Self-determination, Knowledge, Idigenity. Delft:

Eburon Academic Publishers.

Taylor, S. (2010) Narratives of Identity and Place. London: Routledge

Thuen, T. (2003) Lokale diskurser om det samiske. In Bjerkli, B. \& P. Selle (eds)

Samer, makt og demokrati. Samtinget og den nye samiske offentligheten. Oslo:

Gyldendal akademisk.

Valentine, G. (2002) People like Us: Negotiating Sameness and Difference in the Research Process. P.Moss (ed). Feminist Geography in Practice: Research and Methods. Oxford/Massachusetts: Blackwell publishers

Figure 1. Map depicting Norway, Sapmi and Tromsø () Tove Midthun 